\title{
IMPLIKASI SISTEM BAGI HASIL TERHADAP KEBERLANJUTAN USAHA (Studi Kasus di Tambak Udang, Pantai Bayeman, Probolinggo)
}

\section{Implication of Sharing System Towards Business Sustainability (Study in Shrimp Culture, Bayeman Beach, Probolinggo)}

\author{
*Anthon Efani dan Asfi Manzilati \\ Universitas Brawijaya, Indonesia \\ Jalan Veteran, Malang, Indonesia Telp : 0341553512 Fax : 0341557837 \\ Diterima tanggal: 18 April 2018 Diterima setelah perbaikan: 21 Mei 2018 \\ Disetujui terbit: 18 Juni 2018 \\ "email: anthonefani@ub.ac.id
}

\begin{abstract}
ABSTRAK
Tujuan dari penelitian ini adalah untuk mengidentifikasi implikasi sistem bagi hasil terhadap keberlanjutan usaha tambak udang. Dengan mengunakan pendekatan kulitatif, hasil penelitian menunjukkan bahwa sistem bagi hasil telah mendorong usaha tambak udang lebih sustain. Terdapat dua hasil yang menarik yaitu, 1) Sistem penggajian memberikan jaminan biaya hidup bagi keluarga karyawan; 2) Sebagai mitra, ada persentase tertentu dari keuntungan pemilik yang diberikan kepada karyawan. Hal ini membuat karyawan bekerja dengan giat untuk mempertahankan usaha agar tetap berjalan dan berkembang. Sistem ini menjadikan kegiatan usaha tidak perlu pengawasan berlebih dari pemilik tambak. Jaminan biaya hidup dan bagi hasil diharapkan akan mendorong keberlanjutan usaha budidaya udang.
\end{abstract}

Kata Kunci: sistem bagi hasil; sistem penggajian; keberlanjutan usaha tambak udang

\begin{abstract}
This study aims to identify the implication of sharing system toward shrimp-culture business sustainability. By using qualitative approach, the results show that sharing system has encouraged the sustainability of shrimp-culture business. There are two interesting results: (1) The payroll system gives a guaranteed living cost for employees' family. (2) As a partner, there is a certain percentage of profit for employees. It leads the employee try hard to maintain the corporate to keep running and developing. This system makes business activities do not need excessive supervision from the owner. Living cost guarantee and expected return will encourage the sustainability of shrimp-culture business.
\end{abstract}

Keywords: sharing system; payroll system; shrimp-culture business sustainability

\section{PENDAHULUAN}

Masyarakat Indonesia, khususnya Jawa telah lama menjalankan sistem bagi hasil pada usaha tani. Pembiayaan dengan cara sebenarnya secara adat sudah lama dilakukan seperti apa yang disebut dengan praktek maro (Idat, 2001). Kunci keberhasilan pelaksanaan bisnis maro tersebut adalah: Pertama, adanya keteguhan amanah dalam menjalankan bisnis atau kejujuran para pihak, baik bank maupun nasabah sudah mulai terlingkup oleh nuansa kepercayaan untuk melakukan usaha dengan penuh kejujuran dan kesungguhan. Kedua, adanya keterlibatan pemilik modal secara lahiriah dan batiniah. Keterlibatan lahiriah atau fisik diwujudkan dalam bentuk pengawasan dan kunjungan yang dilakukan oleh pemilik modal sedangkan batiniah ini bukan hanya bentuk ucapan-ucapan spiritual tetapi merupakan perwujudan tanggung jawab moral pihak yang dititipi modal dengan kesadaran batin bahwa terdapat sanksi-sanksi yang tersembunyi yang secara moral mencegah pihak yang mengelola untuk melakukan penyimpangan atau tidak jujurnya pengelola, karena penyimpangan atau tindakan yang tidak jujur dapat mengakibatkan pengelola tidak dipercaya lagi dan berarti kehilangan sumber nafkah. Ketiga, rasa self belonging atau rasa memiliki yang mendalam terhadap objek bagi hasil, seperti tanah sawah yang digarap atau ternak sapi yang dibagi hasilkan maka rasa memiliki pengelola demikian tinggi yang diwujudkan dengan pengelolaan dan pemeliharaan 
yang sungguh-sungguh karena semakin baik hasil yang diperoleh semakin banyak keuntungan yang diperoleh oleh kedua belah pihak.

Ketiga hal di atas, yaitu kejujuran, keterlibatan dan rasa memiliki/tanggug jawab yang besar akan menelorkan kerjasama investasi yang win-win and happy business atau kedua belah pihak untung dan senang. Tapi mengapa dalam prakteknya para pelaku bisnis belum apa-apa sudah berkomentar bahwa bagi hasil sulit dilaksanakan, dan sebaliknya di pihak bank selalu dibayangi kekhawatiran pembiayaan menjadi hilang alias rugi.

Pada praktek yang berkembang, dimana telah terjadi masa transisi dari masyarakat agraris menjadi masyarakat industri, menjadikan system bagi hasil mulai banyak ditinggalkan. Manzilati et al. (2010) mengungkapkan bahwa hubungan antara pemilik dengan penggarap bergeser menjadi hubungan antara juragan dengan karyawan/pegawai. Hubungan antara juragan dengan karyawan atau yang dikenal dengan istilah hubungan industrial ini juga tidak menjamin hubungan kerja yang lebih adil dan berjangka panjang, yang pada gilirannya berimplikasi kepada keberlanjutan usaha.

Hal ini sejalan dengan Setiadi (2009) bahwa tingkat upah dan jaminan sosial berbanding terbalik dengan produktivitas kerja karyawan di PT Semarang Makmur Semarang. Dengan demikian tingginya tingkat upah dan jaminan sosial tidak menjamin tingginya produktivitas kerja, tetapi hal tersebut disebabkan faktor-faktor lain di luar upah dan jaminan sosial. Sedangkan menurut Martcahyo et al. (2018) jaminan sosial berpengaruh positif pada kinerja karyawan di bagian produksi PT. Fumira Semarang.

Manzilati (2015) mengungkapkan bahwa terdapat kemiripan antara tambak udang dan usaha tani dalam hal hubungan antara pemilik dan pekerja. Sawah atau lahan tambak, di masa lalu merupakan aset sosial. Artinya, antara pemilik dan penggarap/pekerja memiliki hubungan tetangga dan memiliki "sense of belonging" untuk menjaga keberlangsungan usaha tani/tambak atas lahan tersebut. Hal ini tercermin pada pilihan sistem bagi hasil dalam kerja sama antara keduanya daripada sistem pengupahan. Sistem pengupahan/ penggajian membawa implikasi kepada hubungan industrial antara pemilik dan penggarap hanya sebatas hubungan ekonomi atau bisnis, alih alih hubungan sosial atau kekeluargaan. Namun demikian, beberapa pemilik dan atau pengusaha tambak udang tetap mempertahankan sistem bagi hasil tersebut. Mempertahankan sistem bagi hasil di masa "cash economy" merupakan tantangan yang tidak mudah. Modifikasi dan inovasi atas sistem bagi hasil harus dikembangkan agar sistem ini bertahan dan pada gilirannya menjaga keberlanjutan usaha.

Salah satu usaha tambak yang masih mempertahankan sistem bagi hasil ini adalah usaha tambak yang dikembangkan di daerah pantai Bayeman Probolinggo. Berdasarkan penelitian awal, pengusaha tambak ini memiliki strategi untuk mempertahankan sistem bagi hasil sekaligus memodifikasinya. Hubungan industrial yang dibangunnya dengan pekerja/penggarap bisa jadi menjadi menjadi sistem yang menjaga keberlanjutan usaha sekaligus merupakan best practice yang layak untuk diteliti dan dikembangkan.

\section{Tinjauan Pustaka}

\section{Teori Kontrak Kerja: Hubungan yang Terjadi antara Principal dan Agent}

Teori Agensi merupakan teori yang menjelaskan hubungan antara pemilik modal (principal) yaitu investor dengan manajer (agent). Persoalan agensi (principal-agent) adalah persoalan yang muncul ketika pemilik (perusahaan/ usaha) dan manager (atau pengelola) bukan pihak yang sama. Jensen \& Meckling (1976:308) mendefinisikan hubungan keagenan (agency relationship) sebagai:

\section{“...a contract under which one or more persons (the principal(s)) engage another person (the agent) to perform some service on their behalf which involves delegating some decision making authority to the agent."}

Berdasar definisi tersebut, agen adalah seseorang yang membuat keputusan ekonomi untuk orang lain. Sebagai contoh manajer sebuah perusahaan yang dibayar/digaji untuk bertindak untuk keperluan pemilik.

Perbedaan kepentingan itu dipicu oleh adanya informasi yang tidak simetris. Keadaan informasi asimetris terjadi ketika adanya distribusi informasi yang tidak sama antara principal dan agent. Akibat adanya informasi yang tidak seimbang (asimetri - informasi) ini, timbullah dua permasalahan yang disebabkan karena adanya kesulitan principal memonitor dan melakukan kontrol terhadap tindakan-tindakan agen. 
Yustika (2013) menyatakan permasalahan tersebut adalah:

1. Moral Hazard, yaitu permasalahan yang muncul jika agen tidak melaksanakan hal-hal yang disepakati bersama dalam kontrak kerja.

2. Adverse selection, yaitu suatu keadaan dimana principal tidak dapat mengetahui apakah suatu keputusan yang diambil oleh agen didasarkan pada informasi yang telah diperolehnya, atau terjadi sebagai kelalaian dalam tugas.

Untuk meredam tindakan para agent yang tidak sesuai dengan kepentingannya principal memiliki dua cara yaitu:

1. Mengawasi perilaku agent dengan mengadopsi fungsi audit dan mekanisme corporate governance lain yang dapat meluruskan kepentingan agent dengan kepentingan principal.

2. Menyediakan insentif kepegawaian yang menarik kepada agent dan mengadakan struktur reward yang dapat membujuk para agent untuk bertindak sesuai dengan kepentingan terbaik principal.

Pada konteks hubungan antara pemilik tambak dengan pekerja, hubungan keagenan dapat dijelaskan sebagai berikut. Pemilik tambak merupakan seorang prinsipal, sedangkan pekerja adalah agen. Pemilik sebagai prinsipal tentu mengharapkan keuntungan maksimum dari usaha tambaknya. Sementara pekerja akan bekerja sebatas reward yang dijanjikan oleh prinsipal. Mereka bisa jadi merasa tidak harus bekerja keras melebihi ekspektasi reward yang mungkin diperolehnya. Secara sederhana bentuk hubungan antar keduanya merupakan hubungan internal principal-agent.

\section{Hubungan Sistem Pengupahan}

Sistem pengupahan pada dasarnya adalah sesuatu yang ekuivalen dengan sistem kompensasi. Secara umum, tujuan-tujuan yang hendak dicapai melalui sistem kompensasi atau pengupahan (Handoko, 2001) adalah untuk memperoleh karyawan yang sesuai kualifikasi, mempertahankan karyawan yang ada, menghargai perilaku yang diinginkan, dan mengendalikan biaya-biaya.

Sistem pengupahan merupakan kerangka bagaimana upah diatur dan ditetapkan agar dapat meningkatkan kesejahteraan pekerja.
Menurut Sumarsono (2009), pengupahan di Indonesia pada umumnya didasarkan kepada tiga fungsi upah, yaitu: (a) menjamin kehidupan yang layak bagi pekerja dan keluarganya; (b) mencerminkan imbalan atas hasil kerja seseorang; dan (c) menyediakan insentip untuk mendorong peningkatan produktivitas pekerja. Selanjutnya Sumarsono (2009) menyatakan beberapa ekonom melihat bahwa penetapan upah minimum akan menghambat penciptaan lapangan kerja. Kelompok ekonom lainnya dengan bukti empirik menunjukkan bahwa penerapan upah minimum tidak selalu identik dengan pengurangan kesempatan kerja, bahkan akan mampu mendorong proses pemulihan ekonomi.

Upah merupakan faktor yang sangat penting bagi perusahaan, karenajumlah upah atau balasjasa yang diberikan perusahaan kepada karyawannya akan mempunyai pengaruh yang penting terhadap jalannya perusahaan. Upah yang dimaksud disini adalah balas jasa yang berupa uang atau balas jasa lain yang diberikan lembaga atau organisasi perusahaan kepada pekerjanya. Pemberian upah atau balas jasa ini dimaksud untuk menjaga keberadaan karyawan di perusahaan, menjaga semangat kerja karyawan dan tetap menjaga kelangsungan hidup perusahaan yang akhirnya akan memberi manfaat kepada masyarakat.

Tercapainya tujuan dari sistem kompensasi sangat tergantung kepada terpenuhi syarat/ prinsip yaitu syarat keadilan dan kelayakan (Heidjrachman dan Husnan, 2002). Syarat keadilan berkaitan dengan nilai relatif suatu pekerjaan atau jabatan. Semakin tinggi pengorbanan semakin tinggi penghasilan yang diharapkan. Sedangkan syarat kelayakan berkaitan dengan tercukupinya kebutuhan hidup karyawan.

\section{Implikasi Sistem Kontrak Kerja terhadap Keberlanjutan Usaha}

Keberlanjutan usaha merupakan salah satu implikasi ekonomi yang terjadi dalam kontrak yang dijalankan antara pemilik usaha dan karyawan yang dapat dilihat pada beberapa hal, yaitu pendapatan atau omset, kesinambungan usaha, dan peningkatan produktivitas dari karyawan. Secara rinci implikasi tersebut akan diuraikan berikut ini. Pertama, terkait dengan pendapatan atau omzet dari pemilik usaha satu hal yang menjadi pertimbangan penting bagi seorang pemilik usaha dalam menjalin sebuah kontrak dengan karyawan selaku pelaksana dalam menjalankan usaha. Karena pendapatan merupakan 
salah satu implikasi ekonomi yang mudah dilihat dan dirasakan. Selanjutnya, implikasi yang ketiga adalah peningkatan produktivitas atau etos kera. Seperti halnya kesinambungan dalam menjalankan usaha, peningkatan produktivitasbatau etos kerja ini penting meskipun dari implikasi ini tidak dapat mudah dilihat/diukur secara nominal. Sejalan dengan Renaldi et al. (2013) tentang kontrak pada pemasaran cabai. Petani dan pemasar membuat kontrak yang berisi tentang kesepakatan jumlah, kualitas dan harga cabai agar ketersediaan cabai dapat dipenuhi terus menerus. Selain untuk menjaga stok cabai di pasaran, kontrak tersebut juga menjamin kestabilan pendapatan petani.

\section{METODOLOGI}

\section{Lokasi dan Waktu Penelitian}

Penelitian ini dilakukan di tambak udang Alim Muntasor yang terletak di Pantai Bayeman, Desa Tongas, Kecamatan Bayeman, Kabupaten Probolinggo. Pendekatan yang digunakan pada penelitian ini adalah pendekatan kualitatif. Metode ini dipilih karena penelitian ini bermaksud mengidentifikasi bentuk-bentuk hubungan industrial terkait dengan sistem pengupahan dan atau bagi hasil pada usaha tambak udang. Identifikasi yang dimaksud tidak sekedar mengetahui bentuk sistem kompensasi (pengupahan dan atau bagi hasil yang diterapkan), tetapi juga bagaimana proses dan interaksi pada hubungan industrial tersebut berlangsung. Artinya, penelitian ini berusaha menekankan pada proses yang lebih mendalam ketimbang sekedar memotret hasil akhir dari sebuah proses. Seperti yang didefinisikan Moleong (2006:6) bahwa penelitian kualitatif bermaksud memahami fenomena tentang apa yang dialami oleh subjek penelitian, misalnya: perilaku, persepsi, motivasi, tindakan, dan lain-lain secara holistik, dan dengan cara deskripsi dalam bentuk kata-kata dan bahasa, pada suatu konteks khusus yang alamiah dan dengan memanfaatkan berbagai metode alamiah. Hal ini sejalan dengan uraian Ulin et al. (2002:v) bahwa:

"...ketika tujuan utama sebuah penelitian adalah untuk menggali dan menjelaskan perilaku ketimbang menggambarkannya, ketika masalah penelitian tidak "biasa" dan tidak mencukupi untuk diteliti, atau ketika kata-kata yang pantas untuk dikomunikasikan dengan responden tidak tersedia, maka peneliti disarankan untuk menunjukkan jawaban pertanyaan penelitiannya dengan menggunakan metode kualitatif.

\section{Jenis dan Sumber Data}

Jenis data yang dikumpulkan adalah data primer berupa hasil wawancara mengenai bentukbentuk hubungan industrial terkait dengan sistem pengupahan dan atau bagi hasil pada usaha tambak udang. Penentuan informan dilakukan dengan sengaja mendasarkan pada kriteria tertentu. Informan utama dari penelitian ini adalah pemilik tambak udang dan seluruh pegawai tambak sebanyak 6 orang. Pemilik merupakan informan utama yang ditujukan untuk memperoleh informasi terkait keputusan sistem penggajian dan bagi hasil serta bagaimana mengelola hubungan industrial dengan karyawan. Sedangkan seluruh karyawan dimaksudkan untuk memberikan informasi terkait sistem penggajian dan bagi hasil serta hubungan industrial pada sisi agen. Ini juga sekaligus sebagai sarana triangulasi atas informasi dari pemilik (principal). Sementara itu, informan pendukung adalah para pihak yang berhubungan dengan usaha tambak udang tersebut antara lain suplier pakan, pembeli hasil panen, dan masyarakat yang tinggal di sekitar tambak Alim Muntasor. Hal ini dimaksudkan untuk memperoleh informasi terkait sekaligus untuk alat uji validitas data (triangulasi).

\section{Teknik Pengumpulan Data}

Teknik pengumpulan data dilakukan terutama melalui wawancara mendalam. Wawancara mendalam (tidak terstruktur) dilakukan agar bentuk pengetahuan yang diperoleh dan validitas analisisnya didasarkan pada pemahaman yang mendalam, alamiah dari actor/para pihak dalam penelitian. Metode lain yang digunakan adalah observasi. Observasi ini sekaligus berfungsi untuk memastikan informasi yang diperoleh (triangulasi atas wawancara dan informasi lainnya).

\section{Metode Analisis Data}

Data yang berhasil dikumpulkan untuk selanjutnya ditentukan analisisnya. Proses analisis data dimulai dengan menelaah seluruh data yang tersedia dari berbagai sumber yang masih berhubungan dengan subjek penelitian, yaitu baik itu dari hasil wawancara, pengamatan yang sudah dituliskan dalam catatan lapangan, dokumentasi, dan lain-lain. Lalu diadakan reduksi data dengan jalan melakukan abstraksi. Langkah selanjutnya adalah menyusunnya dalam satuan-satuan. 
Kemudian satuan-satuan itu dikategorisasikan pada langkah selanjutnya. Tahap akhir dari analisis data ini adalah mengadakan pemeriksaan keabsahan data. Dan pada prinsipnya proses analisis data dalam penelitian ini dilakukan secara induksi yaitu lebih mengutamakan dan mementingkan proses daripada hasil.

Selain melakukan analisa data dengan cara di atas, data juga nantinya akan dianalisa dengan mendeskripsikan data yang diperoleh selama proses penelitian berlangsung. Data yang dideskripsikan dapat berupa data primer maupun sekunder, disesuaikan dengan kebutuhan penelitian dan konteks pembahasannya.

\section{HASIL DAN PEMBAHASAN}

Pemberian reward kepada karyawan dilakukan dengan dua system yaitu upah, gaji bulanan dan sharing system. Dua bentuk reward yang diberlakukan oleh pemilik tambak ini terbukti membawa implikasi kepada loyalitas karyawan sekaligus menumbuhkan semangat karyawan untuk bekerja dan memiliki harapan atas keberlangsungan usaha tambak. Selain pada tambak udang, ternyata sistem tersebut juga terjadi pada kegiatan usaha kecil menengah seperti yang dijelaskan oleh Manzilati et al. (2015) bahwa sistem bagi hasil mendorong keberlanjutan usaha pada usaha kecil menengah. Karyawan bekerja keras untuk mendapatkan hasil optimal serta turut berperan untuk mempertahankan kegiatan usaha tersebut. Selanjutnya pada kegiatan usaha tambak udang akan dijelaskan secara rinci mengenai gaji dan sistem bagi hasil sebagai berikut.

\section{Sistem Penggajian}

\section{Gaji Sebagai Jaminan Tercukupinya Biaya Hidup}

Usaha tambak adalah usaha yang memiliki siklus 4 (empat) bulan. Hal ini tentu berbeda dengan perusahaan, manufaktur misalnya, yang memproduksi sekaligus menjual hasil produksinya secara terus menerus. Dengan kata lain, cash-flow pada usaha tambak cenderung pengeluaran terlebih dahulu mulai saat tebar benih sampai udang tersebut siap dipanen dan dijual, baru kemudian ada pemasukan/penerimaan. Sementara itu, karyawan membutuhkan dana untuk memenuhi kebutuhan sehari-hari. Untuk pemenuhan kebutuhan ini, tentu sangat sulit dilakukan jika reward yang diperoleh mengikuti siklus usaha tambak udang.
Berangkat dari pemahaman tersebut, pemilik usaha tambak udang "Alim Muntasor" memberlakukan system penggajian. Penggajian ini diberikan dalam jumlah tetap setiap bulannya. Dengan gaji tetap ini menjamin terpenuhinya kebutuhan sehari-hari karyawan dan keluarganya. Dengan jaminan terpenuhinya kebutuhan ini karyawan menjadi tenang dalam bekerja. Hal ini dinyatakan juga oleh pernyataan karyawan yang mengangap gaji tetap adalah hal yang penting karena merupakan jaminan "bisa makan". Lebih tegas lagi, karyawan memilih keluar dari pekerjaan ini jika tidak ada gaji tetap.

\section{Upah (Harian)}

Di samping karyawan yang dibayar secara bulanan, usaha tambak udang "Alim Muntasor" juga mempekerjakan karyawan secara harian. Karyawan ini direkrut terutama pada saat menjelang dan saat panen. Beberapa orang memang lebih memilih menjadi karyawan harian daripada karyawan tetap. Hal ini dikarenakan dia bisa bekerja pada beberapa tambak yang berbeda. Karyawan tipe ini tidak memperoleh pendapatan lain selain upah harian.

\section{Sistem Bagi Hasil}

Sharing System yang diberlakukan oleh pemilik sangat spesifik dan merupakan modal social yang mereduksi timbulnya persoalan principal - agent. Hubungan yang dibangun oleh pemilik (principal) lebih dari sekedar hubungan industrial antara pemilik (sekaligus pimpinan) dengan karyawan. Lebih dari itu, hubungan yang bersifat kekeluargaan menjadikan monitoring (nyaris) tidak diperlukan disepanjang siklus usaha tambak. Bentuk sharing tersebut dapat dijelaskan ke dalam tiga bentuk yaitu take home pay minimal, bonus dan profit sharing.

\section{a. Take home pay minimal}

Seperti halnya usaha tani, usaha tambah juga menghadapi resiko alam. Lebih dari itu, sifat komoditi ini juga memerlukan perlakuan spesifik. Jika tidak, resiko gagal panen sangat besar. Untuk itu pemilik biasanya melakukan pemanenan secara parsial. Artinya, sebagian demi sebagian udang dipanen dan dijual sebelum benar-benar mencapai umur yang memang tepat untuk dipanen. Hal ini dilakukan untuk mengeliminir kemungkinan kerugian karena gagal panen. Dengan pemanenan parsial ini setidak-tidaknya biaya modal telah kembali. 
Terkait dengan reward untuk karyawan, jika panen dibawah kurang berhasil ataupun gagal sekalipun, pemilik tetap berusaha memberikan tambahan "bonus" sebesar Rp1.300.000 sampai Rp1.500.000. Jumlah ini dimaksudkan untuk memotivasi karyawan untuk tetap optimis terhadap usaha di siklus berikutnya.

\section{b. Bonus sebagai Hadiah atas Kinerja}

Seperti telah disampaikan sebelumnya bahwa pada saat usaha tani kurang berhasil pemilik berusaha memberikan tambahan "bonus" dalam jumlah minimal tertentu. Jika panen berhasil, pemilik tidak segan-segan memberikan bonus yang cukup besar terutama kepada karyawan yang telah lama bekerja dengan loyalitas dan kinerja yang baik. Bentuk bonus biasanya berupa uang tunai yang besarannya tergantung pada penilaian pemilik. Bentuk bonus yang cukup besar yang pernah diberikan adalah sebuah sepeda motor merk Mio G.

\section{c. Sharing atas Keuntungan}

Pada setiap akhir siklus usaha tambak, pemilik berusaha menempatkan karyawan sebagai patner usaha yang layak memperoleh bagian dari usaha di luar gaji. Seperti telah diuraikan sebelumya, bahkan ketika sedang merugipun pemilik berusaha memberikan bonus minimal yang dapat dinikmati oleh karyawan. Terlebih pada saat usaha tambak tersebut memperoleh keuntungan, pemilik akan memberikan persentase tertentu dari keuntungan tersebut kepada karyawan.

Hal unik yang dilakukan pemilik dalam hal penentuan persentase pembagian hasil adalah bahwa semakin kecil keuntungan usaha tambak, maka semakin besar persentase keuntungan yang diberikan kepada karyawan. Pada saat usaha tambak berhasil memperoleh keuntungan yang dianggap pemilik cukup besar, maka prosentase keuntungan yang diberikan kepada karyawan berkisar antara 8-10 persen. Sementara pada saat keuntungan tidak terlalu besar, maka persentasenya akan bertambah dan bahkan pernah seluruh keuntungan habis dibagi kepada karyawan.

\section{KESIMPULAN DAN IMPLIKASI KEBIJAKAN}

\section{Kesimpulan}

Pertama,sistem penggajian memberikan jaminan hidup bagi keluarga karyawan. Kedua, sebagai mitra, sistem bagi hasil membuat karyawan bekerja keras untuk mempertahankan kegiatan usaha terus berjalan dan berkembang. Sehingga membuat kegiatan usaha tersebut tidak terlalu membutuhkan pengawasan berlebih dari pemilik tambak. Jaminan biaya hidup dan bagi hasil mendorong keberlanjutan usaha tambak udang.

\section{Implikasi Kebijakan}

Berdasarkan hasil penelitian rekomendasi yang dapat diberikan adalah pembuatan tata aturan ketenagakerjaan usaha kecil dan menengah terutama pada sektor perikanan melalui pengkombinasian sistem penggajian dan bagi hasil dalam usaha tambak. Perlu adanya pendampingan dari pemerintah bagi pelaku usaha tambak dalam penerapan manajemen sumberdaya manusia agar tercapai kesejahteraan bersama.

\section{UCAPAN TERIMA KASIH}

Penulis menyampaikan ucapan terimakasih kepada Bapak Alim Muntasor dan segenap karyawan tambak udang "Alim Muntasor" yang telah membantu selama proses penelitian. Terimakasih juga diucapkan kepada tim pendukung dalam kegiatan pengumpulan data penelitian.

\section{DAFTAR PUSTAKA}

Handoko, H. 2001. Manajemen Personalia dan Sumber Daya Manusia. BPFE, Yogyakarta

Heidjrachman, R dan S. Husnan. 2002. Manajemen Personalia, BPFE Yogyakarta.

Idat, D.G. 2001. Memberdayakan Sistem Bagi Hasi Bank Syariah Menjadi Win-Win Solution and Happy Bisnis. Pengembangan Perbankan September-Oktober No.912001.

Jensen, M.C and Meckling, W.H. 1976. Theory of the Firm: Managerial Behavior, Agency Cost and Ownership Structure. Journal of Financial Economics. Oktober, 1976, Volume 3. No. 4. Hal 308.

Manzilati, A., N.S. Fadjar dan T. Danarti. 2010. Islamic Entrepreneurial Character and Local Manner: The Javanese Cultural Entrepreneur. The 2nd Indonesia International Conference on Innovation, Entrepreneurship, \& Small Business (IICIES 2010). Tangerang, Indonesia.

Manzilati, A. 2015. How Profit and Loss Sharing System (PLS) Encourage Small \& Medium Enterprises Sustainability. Review of Integrative Business and Economics Research Vol. 4 (3), p 99-107.

Martcahyo, V.A., W. Hidayat dan S. Suryoko. 2018. Pengaruh Pelatihan Kerja, Jaminan Sosial dan 
Insentif Terhadap Kinerja Karyawan Bagian Produksi di PT. Fumira Semarang. https:// ejournal3.undip.ac.id/index.php/jiab/article/ view/833. Diakses pada tanggal 23 Maret 2018.

Moleong, L. 2006. Metodologi Penelitian Kualitatif. PT. Remaja Rosdakarya. Bandung.

Renaldi, E., Karyani T., Sadeli A.H, dan H.N. Utami. 2013. Model Pembiayaan Pra Panen Pada Rantai Pasok Agribisnis Berdasarkansistem Produksi Komoditas Cabai Merah Dengan Orientasi Pasarterstruktur. Sosiohumaniora, Volume 15 no. 3 November 2013: 253 - 260.

Setiadi. 2009. Pengaruh Upah Dan Jaminan Sosial Terhadap Produktivitas Kerja KaryawanDi PT Semarang Makmur Semarang. Thesis

Sumarsono, S. 2009. Ekonomi Sumber Daya Manusia Teori dan Kebijakan Publik. Graha IImu: Yogyakarta.

Ulin, Priscilla, R. Elizabeth, T. Robinson, Elizabeth, E. Tolley, T. Erin. McNeill. 2002. Qualitative Methods; Applied Reseach in Sexual and Reproductive Health. Family Health International. North Carolina. USA. Hal V

Yustika, A.E, 2013. Ekonomi Kelembagaan; Definisi, Teori dan Strategi. Penerbit Erlangga. Jakarta 